\title{
The Impact of Self-assessment and Peer-assessment in Writing on the Self-regulated Learning of Iranian EFL Students
}

\author{
Fathi, Jalil ${ }^{1}$, Mohammad Yousefi, Leila ${ }^{2, *} \&$ Sedighravesh, Mehrnoosh ${ }^{3}$ \\ ${ }^{1}$ TEFL University of Kurdestan \\ ${ }^{2}$ Islamic Azad University, North Tehran branch, Tehran, Iran \\ ${ }^{3}$ Islamic Azad University, Science \& Research Branch, Tehran, Iran \\ *Correspondence: Islamic Azad University, North Tehran branch, Tehran, Iran. Tel: \\ 98-910-114-9578 E-mail: sobhan3636@yahoo.com
}

Received: May 20, 2017 Accepted: June 23, 2017 Published: June 25, 2017

doi:10.5296/jsr.v8i2.11252 URL: https://doi.org/10.5296/jsr.v8i2.11252

\begin{abstract}
Like other types of assessment subscribing to edumetrics as a reaction against traditional psychometrics paradigm, self-assessment and peer-assessment have enjoyed much popularity among various types of alternative assessment. Additionally, alternative assessments, especially self- and peer-assessments have been the focal point of departure as far as L2 writing has been concerned. Furthermore, self-regulation as a burgeoning area of research in L2 learning refers to the degree to which language learners can regulate aspects of their thinking, motivation and behavior during learning. Given the significance of both assessment and self-regulated learning in ELT, the present paper investigated the effect of the implementation of self-assessment and peer-assessment in a writing course on the self-regulated learning of a sample of Iranian EFL students. In so doing, sixty three English major Iranian students who were the students of three intact classes at Islamic Azad University participated in this study. One of the classes was regarded as the self-assessment group, the other group was assigned to peer-assessment group and the third class served as the control group of the study. The ANCOVA analyses of the self-regulation scale scores for the control and experimental groups revealed that both self-assessment and peer-assessment practices had a positive impact on the self-regulated learning of the participants. The results will have theoretical and pedagogical implications for Iranian English language education.
\end{abstract}

Keywords: Self-assessment; Peer-assessment, Writing Course; EFL Students; Self-regulated Learning 


\section{Introduction}

Over the past few decades, many scholars, practitioners and theorizers in English Language Teaching (ELT) have acknowledged their attention to learner variables and learners strategies as influential elements contributing to the success of learners in L2 learning (Reiss, 1985; Tamada, 1996). As an attempt in this area, one major concern has been the existence of sense of personal responsibility and control among the learners to master and acquire the knowledge and skills by their own. This conceptualization has been introduced as a construct called self-regulation which is characterized as people's ability to regulate and direct their feelings, thoughts, and behaviors (Bandura, 1986), self-regulation is a concept in psychology, which has gained much interest (Boekaerts \& Corno, 2005). From this perspective, self-regulated learners are aware when they know a fact or possess a skill and when they do not. Self-regulated students assertively struggle to obtain information when needed and take the necessary steps to master it. In facing barriers such as poor study conditions, confusing teachers, or less-understood text books, they are most likely to come up with a solution to succeed. Self-regulated learners view acquisition as a systematic and controllable process, and they accept greater responsibility for their achievement outcomes (Zimmerman \& Martinez-Pons, 1990). Kanlapan and Velasco (2009, p. 79) identified self-regulation as "any thought, action, or feeling towards attaining educational goals and evidently the management of one's own thinking." Similar accounts have been given by Zimmerman (2000, 2002) to whom self-regulation refers to planned self-generated thoughts, feelings, and actions leading to the attainment of goals with the use of feedback from prior performance which makes the process cyclical.

Recently, numerous ELT theoreticians and practitioners have championed and called for the application of assessment types other than decontextualized, traditional norm-referenced tests (Gipps,1994). This change of orientation has even been viewed as a paradigm shift, from psychometrics to a broader model of educational assessment, from a testing and examination culture to an assessment culture (Gipps,1994). In spite of the potential impact of such alternative assessments as a key element in learning enhancement, research in this area is still alluring and burgeoning. Alternative assessment concepts and taxonomies have also been extensively discussed by ELT members and scholars (Hamp-Lyons, 2009; Leung, 2007; Rea-Dickins \& Gardner, 2000). Overall, given the significance of both assessment and self-regulated learning in ELT, the present paper aimed to explore the effect of the implementation of self-assessment and peer-assessment in a writing course on the self-regulated learning of a sample of Iranian EFL students.

\section{Literature Review}

With the emergence of assessment paradigm, the current belief is that in order to assess students` learning outcomes, practitioners and teachers need to employ a variety of assessment methods (Pope, 2005); nevertheless, in traditional classroom settings, the teacher is still the sole evaluator. Teacher assessment as the sole assessment tradition in language classes is no longer valid nowadays (Leung, 2007). In recent years, different types of assessment have 
received adequate attention as an integral element of learning in general and language learning in particular. Assessment refers to "any methods used to better understand the current knowledge that a student possesses" (Collins \& O'Brien, 2003, p. 29). Given the instructional value of assessment, ELT teachers spend a great deal of their class time engaged in one type of assessment or another (Stiggins, 2002). Nowadays, various innovations in assessment procedures have been carried out, where the attention from summative assessment has shifted to formative assessment. These innovations involve thinking of alternatives, which require questioning the learning process and using learning and assessment activities together rather than habitual testing applications. Therefore, to overcome the inherent limitations of teacher assessments, alternative assessment, such as self-assessments and peer-assessments, gained momentum in the field of education (Hargreaves, Earl, \& Schmidt, 2001).

Self-assessment is conceptualized as "procedures by which the learners themselves evaluate their skills and knowledge" (Bailey, 1998, p. 227). The main merit attributed to self-assessment is that it encourages students to get more actively engaged in the educational process by requiring them to reflect on their own performances and by encouraging them to take greater responsibility for goal-setting and decision making about their own learning (Hughes, \& Mylonas, 2002). According to Boud (1995), self-assessment is the technique by which students judge and give feedback on their own performance, which is aimed at improving students' active participation in classroom activities. Boud and Lablin (1983 as cited in Boud 1989) categorized self-assessment as one of the most important processes that can occur in undergraduate education because of its potential to develop in students the ability to accurately judge their own performances and to monitor their own learning. Brown and Hudson (1998) also stated that students 'greater autonomy in self-assessment can substantially increase their motivation to learn the language. Oscarson (1997) asserts that the self-assessment of language proficiency is concerned with knowing how, under what circumstances and with what effects learners and users of a second language (SL) or a foreign language (FL) judge their own ability in the language. From this perspective, ability is concerned with both achievement and proficiency. Self-assessment, according to Oscarson (1997) comes from the realization that effective learning is best achieved if the student is actively involved in all phases of the learning process. Self-assessment fosters learning autonomy and positively contributes to motivation and outcomes of learning mainly when self-assessment becomes part of day-to -day teaching and when learners do self-assessment for monitoring progress and improvement, not for a grade or placement.

Peer-assessment is also defined as "an arrangement for peers to consider the level, value, worth, quality or successfulness of the products or outcomes of learning of similar status" (Smith, Swanson, \& Elliot, 2000, p. 150). Freeman (1995) highlighted the efficacy of peer-assessment to compensate for weaknesses in many assessment practices that usually fail to foster the development of independent, reflective, critical learners. Similarly, Cheng and Warren also asserted that peer-assessment "... provides learners with the opportunity to take responsibility for analyzing monitoring and evaluating aspects of both the learning process and product of their peers" (2005, p. 94). 
Peer and self-assessment, in which learners assess each other and themselves, has the potentiality to encourage the learners to take greater responsibility for their own learning by getting engaged with assessment criteria and reflection of their own performance and that of their peers. Topping (1998) believes that peer-assessment is an arrangement where individuals consider the amount, level, worth, and quality of success of the products or outcomes of learning of peers of similar status. According to Henner-Stanchina and Holec (1985), self-assessment is an assessment technique that refers to the process whereby "learners simultaneously create and undergo the evaluation procedure, judging their achievement in relation to themselves against their own personal criteria, in accordance with their own objectives and learning expectations."

Concerning self-regulation as the dependent variable of the current study, Zimmerman and Bandura (1994) maintain that self-regulation refers to learners' mind generating concepts which assist them in their feelings and activities towards completing desired educational goals. Despite the fact that definitions of self-regulated learning differ on the basis of researchers' theoretical viewpoint, a shared conceptualization of multiple descriptions and definitions of the construct consider self-regulated learners as metacognitively, motivationally, and behaviorally active participants in their own learning (Zimmerman, 1986). Concerning metacognitive processes, self-regulated learners plan, set goals, organize, self-monitor, and self-evaluate at various points during the process of acquisition (Zimmerman, 2008). Such processes pave the way for them to be self- aware, knowledgeable, and decisive in their approach to learning. As far as motivational processes are concerned, self-regulated learners report high self-efficacy, self-attributions, and intrinsic task interest (Zimmerman, 1985). Such learners are self-starters who display extraordinary effort and persistence during learning. With regard to their behavioral processes, self-regulated learners select, structure, and create environments that optimize learning (Zimmerman \& Martinez-Pons, 1986).

With regard to previous empirical studies investigating the link between assessment and self-regulation, Huang (2011) examined two types of classroom assessment events, the more closed convergent assessments (CA) versus the more open-ended divergent assessments (DA), to investigate whether they affect learners differently in terms of motivation and learning strategies. Participants were intact groups including 105 college freshmen in Taiwan with the same instructor placed under one listening and two speaking classes. Each student experienced two types of assessment, a more traditional test (the CA) and a group performance assessment (the DA). After their experience of each assessment event, students immediately reported their task-specific motivation and learning strategies. Results indicated that CAs were better received by high self-efficacious students and DAs by low scorers.

In a study conducted by Zimmerman and Schunk (2007), it was argued that learners' metacognitive strategy use and affective factors had significant impact on their performance. Likewise, Zimmerman (2008) explored the relationship between self-regulation and motivation. He assereted that "SRL[self-regulated learning] was viewed as proactive processes that students use to acquire academic skill, such as setting goals, selecting and deploying strategies, and self-monitoring one's effectiveness, rather than as a reactive event that happens to students due to impersonal forces"(P. 166-167). In another study conducted by Kostons, van 
Gog, \& Paas (2012), the impact of training self-assessment and task-selection skills on self-regulated learning was investigated. The study consisted of two experiments: In experiment 1 , the hypothesis was examined and confirmed that observing a human model engaging in self-assessment, task selection, or both could be effective for secondary education students' acquisition of self-assessment and task-selection skills. Experiment 2 investigated and confirmed the hypothesis that secondary education students' acquisition of self-assessment and task-selection skills, either through examples or through practice, could improve the efficacy of self-regulated learning. Their final conclusion was that self-assessment and task-selection skills are highly instrumental in self-regulated learning and that training such skills can significantly enhance the degree of knowledge students can acquire from self-regulated learning in which they have freedom over the selection of their learning tasks. In addition, Nicol (2009) investigated the impact of assessment and feedback practices on the first-year experience of learners. More specifically, the study explored how formative assessment and feedback might be used to boost the first-year experience and enable students to develop the skills required for self-regulated learning.

Overall, considering the results of the above empirical studies and the significance of both peer- or self-assessment and self-regulation, this study investigated the effectiveness of the implementation of self-peer-assessment in a course of writing in enhancing self-regulated learning among Iranian EFL learners. To accomplish this purpose, the following research questions were formulated:

1. Does practicing self-assessment in a writing course have any significant effect on the self-regulation of Iranian EFL students?

2. Does practicing peer-assessment in a writing course have any significant effect on the self-regulation of Iranian EFL students?

3. Does practicing self-assessment in a writing course improve the self-regulation of Iranian EFL students more than practicing peer-assessment in a writing course?

\section{Participants}

To accomplish the purpose of the current study, a sample of 69 intermediate Iranian EFL students were recruited. The participants were students of either English literature or English translation at Islamic Azad University South Tehran Branch and Central Tehran Branch. The sample included both male and female students whose age ranged from 20 to 27 with the average age of 21.19. The students enrolled in a writing course which is a two-credit course offered to the students in their the bachelor's program. The course lasted for 12 weeks. The sample of the present study were students of three intact classes. The classes were randomly assigned to control and experimental conditions. The self-assessment group included 22 students, the peer-assessment group consisted of 24 individuals and the control group constituted 23 EFL learners. Due to the possible relationship between academic achievement and self-regulated learning (Zimmerman, 1989), prior to the initiation of the experiment, the OPT as the proficiency test was administered to all the students of the three groups. After the administration of the OPT, the mean scores of the three groups were computed and compared 
with one another. To ensure the homogeneity of the groups in terms of general language proficiency, a one-way ANOVA was run to examine the existing difference between groups, as measured by the OPT. The result of one-way ANOVA (Table 1) revealed that the groups were not significantly different in terms of language proficiency before the experiment at the $\mathrm{p}<.05$ level in OPT scores for the three groups: $F(2,66)=0.08, \mathrm{p}=.91$.

Table 1. ANOVA

\begin{tabular}{cccccc}
\hline & $\begin{array}{c}\text { Sum of } \\
\text { Squares }\end{array}$ & df & $\begin{array}{c}\text { Mean } \\
\text { Square }\end{array}$ & F & Sig. \\
\hline Between Groups & 10.571 & 2 & 5.285 & .084 & .919 \\
Within Groups & 4140.415 & 66 & 62.734 & & \\
Total & 4150.986 & 68 & & & \\
\hline
\end{tabular}

\section{Instruments}

\subsection{Self-Regulated Language Learning Questionnaire (SRLLQ)}

The five-point Likert-type questionnaire was developed and validated by Seker (2015). It was used to find out learners' self-reported Self-Regulated Learning (SRL) use was adapted from previous models of SRL. The questionnaire was mainly based on Boekaerts' (1997) Self-Regulated Learning Model and Oxford's (1990) Strategy Inventory for Language Learning (SILL). The questionnaire consisted of 30 items including five subscales of internal motivation $(n=5)$, external motivation $(n=4)$, cognitive strategies $(n=7)$, metacognitive strategies $(n=10)$, and evaluation $(n=4)$. The computed Cronbach's alpha value in the current study was 0.81 at pretest and 0.83 at posttest.

\subsection{Proficiency Test}

Oxford Placement Test (OPT, 2004), was used as the proficiency test to measure the proficiency level of the individuals. OPT includes 200 items, measuring listening as well as grammar, vocabulary and reading skills. OPT is a reliable and efficient means of placing students at different levels of language ability. Allen (2004), the designer of the test, claims that the OPT is capable of being used with any number of learners of English to ensure efficient, reliable and accurate grading and placing of students into classes at all levels from elementary to advanced. According to Allen, the OPT has been calibrated against the proficiency levels based on the Common European Framework of Reference for Languages (CEFR), the Cambridge ESOL Examinations, and other major international examinations. The reliability of the test as measured by Cronbach's alpha in the current study 0.81 .

\section{Procedure}

Since intact groups are investigated in the current study, the design is classified as a quasi-experimental design. Quasi-experimental designs lack randomization but employ other strategies to provide some control over extraneous variables (Ary et al., 1990). As previously 
discussed, before the experiment, the OPT serving as the proficiency test was given to the participants in the three groups. The justification for the inclusion of OPT as a test of homogeneity was the fact that prior language competence was considered as a potential variable affecting the participants' degree of self-regulation. The statistical analysis of the results of the OPT scores indicated that the students in the three groups were of the same level of language proficiency before the conduction of the experiment. As the pre-test of the study, SRLLQ was administered to the students to measure their degree of self-regulation before the experiment. For the purpose of the current study, self-assessment and peer-assessment practices were carried out in the two experimental groups. For the first few sessions the fundamentals of paragraph writing such as brainstorming on topic, thesis statement writing, supporting sentences, coherence, cohesion, introductory paragraph, body, and concluding paragraph were explained. The students were trained to produce the final draft of essay after a successive writing of drafts. Afterwards, the experimental group students were instructed on how to use the assessment rubrics in assessing compositions of their own and their classmates. In each session, the learners were assigned a topic by the teacher for paragraph writing. The students in the peer-assessment group exchanged their written paragraphs with those of their peers for peer-assessment while the participants of the self-assessment group rated their own paragraphs themselves.

However, the control group essays were rated by the teacher himself. The students of the control group were supposed to write their own compositions about the given topics and the writings were corrected by the teacher himself without any explicit explanation on rating mechanism. As the final stage, after the conduction of the experiment at the end of the semester, SRLLQ was re-administered to the students of the three groups to investigate any possible change in the self-regulated learning of the students.

\section{Data Analysis and Results}

Prior to analyzing the research questions, the normality of distribution for the scores was examined. The normality of data is a main pre-requisite for running parametric statistical tests. To examine this normality assumption, one-sample Kolmogorov-Smirnov (K-S) test was run for both pre-test and post-test scores of SRLLQ. As it is shown in Table 2., the results of one-sample K-S test showed that the data was normally distributed; as a result, parametric data analysis methods could be employed.

Afterwards, in order to answer the first two research questions of the present study, paired-samples T-test, and to answer the third research question, one-way ANCOVA was conducted, respectively. The first research question investigated the effectiveness of practicing self-assessment in a writing course in enhancing the self-regulated learning of Iranian EFL students, to answer this question a paired-samples T-test was run for the pre-test and post-test scores of the self-assessment group on SRLLQ, this analysis aimed to evaluate the impact of self-assessment implementation in the writing course on students' scores on the SRLLQ post-test scores. The result indicated that there was a statistically significant increase 
in self-assessment group scores of SRLLQ from pretest $(M=49.50, S D=7.5)$ to post-test $(M=$ $66.22, S D=7.8), \mathrm{t}(21)=-8.99, p<.000$ (two-tailed).

Table 2. One-Sample Kolmogorov-Smirnov Test

\begin{tabular}{|c|c|c|c|}
\hline & & pretest & posttest \\
\hline \multicolumn{2}{|c|}{$\mathrm{N}$} & 69 & 69 \\
\hline \multirow[t]{2}{*}{ Normal Parameters ${ }^{\mathrm{a}}$} & Mean & 48.9855 & 61.9855 \\
\hline & Std. Deviation & 7.81306 & 9.77466 \\
\hline \multirow{3}{*}{$\begin{array}{c}\text { Most Extreme } \\
\text { Differences }\end{array}$} & Absolute & .115 & .072 \\
\hline & Positive & .115 & .065 \\
\hline & Negative & -.073 & -.072 \\
\hline \multicolumn{2}{|c|}{ Kolmogorov-Smirnov Z } & .956 & .596 \\
\hline \multicolumn{2}{|c|}{ Asymp. Sig. (2-tailed) } & .320 & .870 \\
\hline
\end{tabular}

In order to address the second research question which investigated the effect of the implementation of peer-assessment practices in a writing course on the self-regulated learning of Iranian EFL students, another paired-samples t-test was conducted to empirically assess the impact of the practicing peer-assessment practices on students' scores on the second administration of SRLLQ. The result of data analysis showed that there was a significant increase in SRLLQ scores from pretest $(M=48.54, S D=8.09)$ to post-test $(M=65.62, S D=$ 9.07), $\mathrm{t}(23)=-10.69, p<.000$ (two-tailed).

However, the data analysis for the control group did not reveal any significant improvement in the SRLLQ scores of control group from pre-test to post-test. There was a statistically significant increase in control group scores from pretest $(M=52.26, S D=8.39)$ to post-test $(M=54.13, S D=7.30), \mathrm{t}(22)=-.98 .11, p<.0005$ (two-tailed). In other words, it can be argued that the students of control group who did not practice self- and peer-assessment practices did not show any significant increase in the degree of self-regulation, suggesting that teacher-assessment failed to contribute to self-regulated learning of the students.

Finally, to answer the third research question which aimed to compare the two experimental groups in improving writing performance a one-way Analysis of Covariance (ANCOVA) was run. According to Pallant (2007), ANCOVA can be used when you have a pre-test/post-test design (e.g. comparing the impact of two different interventions, taking before and after measures for each group). In the current study, the pre-test scores on SRLLQ are considered as a covariate to 'control' for pre-existing differences between the groups.

In order to use ANCOVA as a statistical method, one important assumption is the homogeneity of regression slopes which concerns the relationship between the covariate and the dependent variable for each of the groups (Pallant, 2007). According to this assumption, there should be no interaction between the covariate and the treatment or experimental manipulation. As seen 
in Table 3, this assumption has not been violated in the present study; If the significance level for the interaction is less than or equal to .05, the interaction is statistically significant, indicating that we have violated the assumption. As Table 3 indicates the Sig. level for group * pretest is .109 suggesting that this assumption has not been violated.

Table 3. Tests of Between-Subjects Effects

\begin{tabular}{llllll}
\hline \multicolumn{1}{c}{ Source } & $\begin{array}{c}\text { Type III Sum } \\
\text { of Squares }\end{array}$ & df & Mean Square & F & Sig. \\
\hline Corrected Model & $4094.611^{\mathrm{a}}$ & 5 & 818.922 & 21.475 & .000 \\
Intercept & 1554.121 & 1 & 1554.121 & 40.755 & .000 \\
group & 380.434 & 2 & 190.217 & 4.988 & .010 \\
pretest & 1696.812 & 1 & 1696.812 & 44.497 & .000 \\
group * pretest & 175.499 & 2 & 87.749 & 2.301 & .109 \\
Error & 2402.374 & 63 & 38.133 & & \\
Total & 271609.000 & 69 & & & \\
Corrected Total & 6496.986 & 68 & & & \\
a. R Squared $=.630$ (Adjusted R Squared $=.601)$ & & \\
\hline
\end{tabular}

After checking the homogeneity of regression slopes, a one-way between-groups analysis of covariance was run to compare the effectiveness of three experimental conditions on the self-regulated learning of Iranian EFL students. The independent variable was the type of experimental condition (self-assessment, peer-assessment and teacher-assessment), and the dependent variable was the set scores on the SRLLQ administered after the treatment. Students' scores on the pre-test administration of the SRLLQ were employed as the covariate in the present analysis.

Preliminary checks were conducted to ensure that there was no violation of the assumptions of normality, linearity, homogeneity of variances, homogeneity of regression slopes, and reliable measurement of the covariate. After adjusting for pre-intervention scores, as the Table 4 shows that there was significant difference among the three intervention groups on post-intervention scores on the SRLLQ, $F(2,65)=26.70, P=.000$, partial eta squared $=.45$.

Table 4. Tests of Between-Subjects Effects

\begin{tabular}{lllllll}
\hline \multicolumn{1}{c}{ Source } & $\begin{array}{c}\text { Type III Sum } \\
\text { of Squares }\end{array}$ & df & $\begin{array}{c}\text { Mean } \\
\text { Square }\end{array}$ & F & Sig. & $\begin{array}{c}\text { Partial Eta } \\
\text { Squared }\end{array}$ \\
\hline Corrected Model & $3919.113^{\mathrm{a}}$ & 3 & 1306.371 & 32.940 & .000 & .603 \\
Intercept & 1495.086 & 1 & 1495.086 & 37.698 & .000 & .367 \\
pretest & 1786.224 & 1 & 1786.224 & 45.039 & .000 & .409 \\
group & 2118.413 & 2 & 1059.207 & 26.707 & .000 & .451 \\
Error & 2577.873 & 65 & 39.660 & & & \\
Total & 271609.000 & 69 & & & & \\
Corrected Total & 6496.986 & 68 & & & & \\
a. R Squared $=.603$ (Adjusted R Squared =.585) &
\end{tabular}


Moreover, to pinpoint specifically where between the groups the mean differences existed, the Scheffe test as a post hoc test was run (Table 5).

As seen in Table 5, the mean differences between peer-assessment and self-assessment groups are not significant but the mean differences between peer-assessment and control groups and also between self-assessment and control groups are significant $(p<.01)$. In other words, the experimental conditions in both self-assessment and peer-assessment groups have been effective in enhancing the self-regulated learning of the students of the groups. However, it was revealed that there was not significant difference between the two groups of self-assessment and peer-assessment in terms of self-regulation after the treatment.

Table 5. Multiple Comparisons

\begin{tabular}{|c|c|c|c|c|c|c|}
\hline \multirow[t]{3}{*}{ (I) group } & \multirow[t]{3}{*}{ (J) group } & \multirow{3}{*}{$\begin{array}{l}\text { Mean } \\
\text { Difference } \\
(\mathrm{I}-\mathrm{J})\end{array}$} & \multirow{3}{*}{$\begin{array}{l}\text { Std. } \\
\text { Error }\end{array}$} & \multirow[t]{3}{*}{ Sig. } & \multicolumn{2}{|c|}{$95 \%$ Confidence Interval } \\
\hline & & & & & Lower & Upper \\
\hline & & & & & Bound & Bound \\
\hline \multirow[t]{2}{*}{ peer-assessment } & self-assessment & -.60227 & 2.40014 & .966 & -6.3571 & 5.1526 \\
\hline & control & $11.49457^{*}$ & 2.37276 & .000 & 5.8054 & 17.1837 \\
\hline \multirow[t]{2}{*}{ self-assessment } & peer-assessment & .60227 & 2.40014 & .966 & -5.1526 & 6.3571 \\
\hline & control & $12.09684^{*}$ & 2.42497 & .000 & 6.2825 & 17.9112 \\
\hline \multirow[t]{2}{*}{ control } & peer-assessment & $-11.49457^{*}$ & 2.37276 & .000 & -17.1837 & -5.8054 \\
\hline & self-assessment & $-12.09684^{*}$ & 2.42497 & .000 & -17.9112 & -6.2825 \\
\hline$*$. The mean di & rence is significan & at the 0.051 & & & & \\
\hline
\end{tabular}

\section{Discussion}

The findings of the present study revealed that the implementation of self-assessment and peer-assessment in the writing course significantly contributed to the enhancement of EFL learners' self-regulation. This result is in line with those of Brookhart and Durkin (2003); Nicol and Macfarlane-Dick (2006); Huang (2011), Kostons, van Gog, \& Paas (2012) who favor the learner-centered assessment in enhancing self-regulatory strategies.

As far as assessment or edumetrics is concerned, Brookhart and Durkin (2003) pointed out that performance assessments as a subcategory of assessment are superior to tests regarding productive goal orientation and learning strategies due to the fact that they provide opportunities for both high- and low-efficacious students to achieve. Similarly, Kostons, van Gog, \& Paas (2012) maintained that in order for self-regulated learning to be more effective, the engagement of the students in accurate self-assessment of their own performance on a learning task can be highly influential. Their final conclusion was that "self-assessment and task-selection skills indeed play an important role in self-regulated learning and that training these skills can significantly increase the amount of knowledge students can gain from self-regulated learning in which they choose their own learning tasks" (p. 121).

In both self-assessment and peer-assessment, the learners are directly engaged in training self-monitoring, self-evaluation and task-selection skills in all of which the learners have much control over the learning tasks they are engaged in. Prior research provides adequate support 
that modeling can improve certain self-regulatory processes (Kitsantas et al., 2000; Zimmerman \& Kitsantas, 2002).

Assigning control and freedom to learners over the learning tasks they work on is believed to enhance their self-regulated learning skills and to lead to personalized learning trajectories (Hannafin, 1984; Williams, 1996). In the current study the control group in which the teacher-assessment was undertaken in the writing course did not significantly contributed to the students' self-regulation. The reason may lie in the superiority of personalized instructions to public instruction. Instead of having all learners follow the same uniform instruction, which is often more appropriate for the average learners, personalized instruction permits learners who have difficulty with a task or topic to start at a lower level of intricacy or gain more assistance, while learners who find the new material easy can quickly move on to more complex materials. As a result, such a personalized and individualized instruction is believed to foster students' motivation and learning outcomes more than public instruction prescribed for all students (Niemiec et al., 1996; Pintrich, 2004; Schnackenberg \& Sullivan, 2000).

\section{Conclusions}

The present study aimed at the investigation of the impact of the implementation of self-assessment and peer-assessment in a writing course on the self-regulated learning of Iranian EFL students. The findings of the study revealed that that the self-regulation of the learners who practiced both self- and peer-assessment practices in the writing course improve significantly. Nevertheless, further analysis of the data revealed that there was not statistically significant difference between the students of peer-assessment and self-assessment groups in the degree of self-regulated learning after the treatment. Such results corroborate the previous empirical and theoretical evidence in support of alternative assessment in enhancing the amount of learning. Concerning the efficacy and the instructional value of alternative assessment in ELT, from the pedagogical point of view, it can be recommended that the teachers and ELT practitioners pay more serious attention to alternative assessment and include more peer-assessment and self-assessment practices in their language teaching methodology; in addition, policy-makers, textbook designers and material developers are also encouraged to take it as an imperative to include peer-assessment and self-assessment practices in their prospectively developed ELT materials and textbooks.

\section{References}

Ary, D., Jacobs, C., \& Razavieh, A. (1990). Introduction to research in education. Fort Worth, TX: Holt, Rinehart and Winston, Inc.

Allen, D. (2004). Oxford placement test 1. Oxford: OUP.

Bailey, K. M. (1998). Learning about language assessment. Cambridge, Heinle \& Heinle.

Bandura, A. (1986). Social foundations of thought and action: Asocial cognitive theory. 
Engle wood cliffs, NJ: Prentice- Hall.

Boekaerts, M., \& Corno, L. (2005). Self-regulation in the classroom: A perspective on assessment and intervention. Applied Psychology: An International Review, 54(2), 199231. https://doi.org/10.1111/j.1464-0597.2005.00205.x

Boud, D. (1989). The role of self-assessment in student grading. Assessment and Evaluation in Higher Education, 14, 22-30. https://doi.org/10.1080/0260293890140103

Boud, D. (1992). The use of self-assessment schedules in negotiated learning. Studies in Higher Education, 17, 185-200. https://doi.org/10.1080/03075079212331382657

Boud, D. (1995). Enhancing learning through self-assessment. London: Kogan Page.

Brookhart, S. M., \& Durkin, D. T. (2003). Classroom assessment, student motivation, and achievement in high school social studies classes. Applied Measurement in Education, 16(1), 27-54. https://doi.org/10.1207/S15324818AME1601_2

Collins, J. W., 3rd, \& O'Brien, N. P. (Eds.). (2003). Greenwood Dictionary of Education. Westport, CT: Greenwood.

Conway, R., \& Kember, D. (1993). Peer assessment of an individual's contribution to a group project. Assessment \& Evaluation in Higher Education, 18(1), 45-54. https://doi.org/10.1080/0260293930180104

Evans, A. W., \& McKenna, C. (2005). Trainees` perspectives on the assessment and self-assessment of skills. Assessment \& Evaluation in Higher Education, 30(2), 163-174. https://doi.org/10.1080/0260293042000264253

Freeman, M. (1995). Peer assessment by groups of group work. Assessment \& Evaluation in Higher Education, 20(3), 289-301. https://doi.org/10.1080/0260293950200305

Gipps, C. V. (1994). Beyond testing: Towards a theory of educational assessment. London: The Falmer Press.

Goldfinch, J. M. (1994). Further developments in peer assessment of group projects. Assessment and Evaluation in Higher Education, 19(1), 29-35. https://doi.org/10.1080/0260293940190103

Hamp-Lyons, L. (2009). Principles for large-scale classroom-based teacher assessment of English learners' language: An initial framework from school-based assessment in Hong Kong. TESOL Quarterly, 43(3), 524-529. https://doi.org/10.1002/j.1545-7249.2009.tb00249.x

Hannafin, M. J. (1984). Guidelines for using locus of instructional control in the design of computer-assisted instruction. Journal of Instructional Development, 7(3), 6-10. https://doi.org/10.1007/BF02905753

Hargreaves, A., Earl, L., \& Schimidt, M. (2001). Perspectives on alternative assessment reform. American Educational Research Journal, 39(1), 69-95. 
https://doi.org/10.3102/00028312039001069

Henner-Stanchina, C., \& Holec, H. (1985). Evaluation in an autonomous learning schema. In P. Riley (Ed.), Discourse and learning. London: Longman.

Hughes, K., \& Mylonas, A. (2002). Developing procedures for implementing peer assessment. Assessment \& Evaluation in Higher Education, 27(5), 427-441. https://doi.org/10.1080/0260293022000009302

Kanlapan, T. E., \& Velasco, J. C. (2009). Constructing a self-regulated scale contextualized in writing. TESOL Journal, 1(1), 79-94.

Kitsantas, A., Zimmerman, B. J., \& Cleary, T. (2000). The role of observation and emulation in the development of athletic self-regulation. Journal of Educational Psychology, 92, 811-817. https://doi.org/10.1037/0022-0663.92.4.811

Kostons, D., van Gog, T., \& Paas, F. (2012). Training self-assessment and task-selection skills: A cognitive approach to improving self-regulated learning. Learning and Instruction, 22, 121-132. https://doi.org/10.1016/j.learninstruc.2011.08.004

Leung, C. (2004). Developing formative teacher assessment: Knowledge, practice, and change. Language Assessment Quarterly, 1(1), 19-41. https://doi.org/10.1207/s15434311laq0101_3

Leung, C. (2007). Dynamic assessment: Assessment for and as teaching? Language Assessment Quarterly, 4(3), 257-278. https://doi.org/10.1080/15434300701481127

Nicol D. (2009). Assessment for learner self-regulation: Enhancing achievement in the first year using learning technologies. Assessment and Evaluation in Higher Education, 34, 335-352. https://doi.org/10.1080/02602930802255139

Nicol D. (2010). From monologue to dialogue: Improving written feedback processes in mass higher education. Assessment and Evaluation in Higher Education, 35, 501-517. https://doi.org/10.1080/02602931003786559

Mendonça, C. O., \& Johnson, K. E. (1994). Peer review negotiations: revision activities in ESL writing instruction. TESOL Quarterly, 28(4), 745-769. https://doi.org/10.2307/3587558

Niemiec, R. P., Sikorski, C., \& Walberg, H. J. (1996). Learner-control effects: a review of reviews and a meta-analysis. Journal of Educational Computing Research, 15, 157e174. https://doi.org/10.2190/JV1U-EQ5P-X2PB-PDBA

O'Leary, Ch. (2007). Should learner autonomy be assessed? Proceedings of the Independent Learning Association, Japan.

Orsmond, P., \& Merry, S. (1997). A study in self-assessment. Assessment \& Evaluation In Higher Education, 22(4), 357-370. https://doi.org/10.1080/0260293970220401

Oscarson, M. (1997). Self-assessment of foreign and second language proficiency . In C. 


\section{MInstitute Macrothink}

Clapham, \& D. Corson (Eds.), Encyclopedia of language and education: Language testing and assessment (pp.175-187). Dordrecht, Netherlands: Kluwer Academic. https://doi.org/10.1007/978-1-4020-4489-2_17

Oscarson, M. (1989). Self-assessment of language proficiency: rationale and implications. Language Testing, 6(1), 1-13. https://doi.org/10.1177/026553228900600103

Oxford, R. L. (1990). Language learning strategies: What every teacher should know. Boston: Heinle \& Heinle.

Pallant, J. (2007). SPSS Survival Manual: A Step-by-step Guide to Data Analysis Using SPSS for Windows (3rd ed.). McGraw Hill: Open University Press.

Pintrich, P. R. (2004). A conceptual framework for assessing motivation and self-regulated learning in college students. Educational Psychology Review, 16, 385-407. https://doi.org/10.1007/s10648-004-0006-X

Pope, N. K. L. (2005). The impact of stress in self-assessment. Studies in higher Education, 30(1), 51-63. https://doi.org/10.1080/0260293042003243896

Rea-Dickins, P., \& Gardner, S. (2000). Snares and silver bullets: Disentangling the construct of formative assessment. Language Testing, 17, 215-243. https://doi.org/10.1191/026553200673636547

Reid, J. M. (1987). The process of composition. Englewood Cliffs, NJ: Prentice Hall Regents.

Reiss, M. A. (1985). The good language learner: Another look. Canadian Modern Language Review, 41, 511-523.

Saito, H. (2008). EFL classroom peer assessment: training effects on rating and commenting. Language Testing, 25, 553-581. https://doi.org/10.1177/0265532208094276

Schendel, E., \& O'Neill P. (1999). Exploring the theories and consequences of self-assessment through ethical inquiry. Assessing writing, 6(2), 199-227. https://doi.org/10.1016/S1075-2935(00)00008-8

Slujsmans, D. M. A., Brand-Gruwel, S., \& Marrienboer, G. V. (2002). Peer assessment training in teacher education. Assessment \& Evaluation in Higher Education, 27(5), 443-454. https://doi.org/10.1080/0260293022000009311

Schnackenberg, H. L., \& Sullivan, H. J. (2000). Learner control over full and lean computer-based instruction under differing ability levels. Educational Technology Research and Development, 48(2), 19e35. https://doi.org/10.1007/BF02313399

Stefani, L. A. (1994). Peer, self and tutor assessment: Relative reliabilities. Studies in Higher Education, 22(3), 289-306. https://doi.org/10.1080/03075079412331382153

Stiggins, R. (2002). Assessment crisis: The absence of assessment for learning. Phi Delta Kappan, 83(10), 758-765. https://doi.org/10.1177/003172170208301010 


\section{$\Lambda$ Macrothink}

Tamada, Y. (1996). The relationship between Japanese learners' personal factors and their choices of language learning strategies. Modern Language Journal, 80, 120-131.

Topping, K. (1998). Peer-assessment between students in colleges and universities. Review of Educational Research, 68, 249-276. https://doi.org/10.3102/00346543068003249

Topping, K., Smith, E., Swanson., I., \& Elliot, A. (2000). Formative peer assessment of academic writing. Assessment \& Evaluation in Higher Education, 25(2), 149-169. https://doi.org/10.1080/713611428

Williams, E. (1992). Student attitudes toward learning and assessment. Assessment \& Evaluation in Higher Education, $17(1), \quad 45-59$. https://doi.org/10.1080/0260293920170105

Williams, M. (1996). Learner control and instructional technologies. In D. Jonassen (Ed.), Handbook of research on educational communications and technology (pp. 957 - 983). New York: Scholastic.

Zimmerman, B. J. (1989). Models of self-regulated learning and academic achievement. In B. J. Zimmerman \& D. H. Schunk (Eds.), Self-regulated learning and academic achievement: Theory, research and practice (pp. 1- 25). New York: Springer-Verlag. https://doi.org/10.1007/978-1-4612-3618-4

Zimmerman, B. J. (2000). Attaining Self-Regulation: A Social Cognitive Perspective. In M. Boekaerts, P. R. Pintrich, \& M. Zeidner (Eds.), Handbook of self-regulation (pp. 13-35). San Diego, CA: Academic Press. https://doi.org/10.1016/B978-012109890-2/50031-7

Zimmerman, B. J. (2001). Theories of self-regulated learning and academic achievement: an overview and analysis. In B. J. Zimmerman, \& D. H. Schunk (Eds.), Self-regulated learning and academic achievement (pp. 1-37). Mahwah, New Jersey: Lawrence Erlbaum.

Zimmerman, B. J. (2002). Becoming a self-regulated learner: An overview. Theory into Practice, 41(2), 64-72. https://doi.org/10.1207/s15430421tip4102_2

Zimmerman, B. J. (2008). Investigating self-regulation and motivation: Historical background, methodological developments, and future prospects. American Educational Research Journal, 45(1), 166-183. https://doi.org/10.3102/0002831207312909

Zimmerman, B. J., \& Kitsantas, A. (2002). Acquiring writing revision and self-regulatory skill through observation and emulation. Journal of Educational Psychology, 94, 660-668. https://doi.org/10.1037/0022-0663.94.4.660

Zimmerman, B. J., \& Martinez-Pons, M. (1986). Developing of a structured interview for assessing student use of self-regulated learning strategies. American Educational Research Journal, 23(4), 614-628. https://doi.org/10.3102/00028312023004614

Zimmerman, B. J., \& Schunk, D. H. (2007). Motivation: An essential dimension of self-regulated learning. In D. H. Schunk and B. J.Zimmerman (Eds.), Motivation and 
self-regulated learning: Theory, research, and applications. Mahwah, NJ: Lawrence Erlbaum, 1-30.

\section{Copyright Disclaimer}

Copyright for this article is retained by the author(s), with first publication rights granted to the journal.

This is an open-access article distributed under the terms and conditions of the Creative Commons Attribution license (http://creativecommons.org/licenses/by/3.0/). 